\title{
Effects of Interest Rate on Stock Market Returns in Kenya
}

\author{
Donald A. Otieno ${ }^{1}$, Rose W. Ngugi ${ }^{1} \&$ Nelson H. W. Wawire ${ }^{2}$ \\ ${ }^{1}$ School of Economics, University of Nairobi, Kenya \\ ${ }^{2}$ School of Economics, Kenyatta University, Kenya \\ Correspondence: Donald A. Otieno. School of Economics, University of Nairobi, P. O. Box 77082-00611, \\ Nairobi, Kenya. Tel: 254-728-842-110. E-mail: otienodonald38@gmail.com
}

Received: May 31, 2017

Accepted: June 16, 2017

Online Published: July 5, 2017

doi:10.5539/ijef.v9n8p40

URL: https://doi.org/10.5539/ijef.v9n8p40

\begin{abstract}
Debate on the stochastic behaviour of stock market returns, 3-month Treasury Bills rate, lending rate and their cointegrating residuals remains unsettled. This study examines the stochastic properties of the macroeconomic variables, stock market returns and their cointegrating residuals using an Autoregressive Fractionally Integrated Moving Average (ARFIMA) model. It also investigates Granger causality between the two measures of interest rate and stock market returns. The study uses monthly data from $1^{\text {st }}$ January 1993 to $31^{\text {st }}$ December 2015 . The results indicate that the 3-month Treasury Bills rate, lending rate and stock market returns are fractionally integrated which implies that shocks to the variables persist but eventually disappear. The results also reveal that the cointegrating residuals are fractionally integrated which suggests that a new and harmful long-run equilibrium might be established when each of the measures of interest rate is driven away from stock market returns. Additionally, the results indicate that the 3-month Treasury Bills rate and lending rate negatively Granger cause stock market returns in the long run. This suggests that stocks and Treasury Bills are competing investment assets. On the other hand, ARFIMA-based Granger causality reveals that stock market returns lead the 3-month Treasury Bills rate and lending rate with a negative sign in the short run. This implies that a prosperous stock market results into a favorable macroeconomic environment. A key contribution of this study is that it is the first to empirically examine fractional cointegration and ARFIMA-based Granger Causality between interest rate and stock market returns in Kenya.
\end{abstract}

Keywords: ARFIMA models, interest rate, stock market returns

\section{Introduction}

Stock market returns provide useful signals regarding the future state of the economy, including the economic and financial status (Hamrita \& Trifi, 2011). Specifically, stock market returns drive the allocation of resources across sectors of the economy. Their stochastic behaviour also provides information concerning market expectations and risk attitudes of investors in the market. Additionally, even though macroeconomists, financial economists and actors in the financial market use stock market indices to understand trends in the economy, describe stock markets and compare returns on specific investments (Hautcoeur, 2011), stock market returns are more preferred because they provide traders and investors with a scale-free summary of the ever rapid inflow of information into the stock market (Lo, Campbell, \& Mackinlay, 1997). Equally, given their more attractive statistical properties (Lo et al., 1997), stock market returns are useful to policymakers, researchers and stock market participants keen on making various forecasts, developing regulatory rules, constructing portfolio strategies or determining implications of policy. On the whole, understanding the trends of stock market returns is critical to evaluating the events in the financial market and monitoring the evolution of the economy. Nonetheless, stock market returns are systematically influenced by various types of information which arrives randomly to the stock market. A key type of such influential information is news regarding the evolution of interest rate (Chen, Roll, \& Ross, 1986; Gupta \& Modise, 2013).

Interest rate, in the form of a risk free rate, plays a significant role in investment practice in that it is considered as a rate of return on an investment which has an assured or nearly assured payoff. Consequently, investors use the risk free-rate such as the Treasury Bills rate as a reference rate when making investment decisions on the valuation of stocks. Furthermore, since the required rate of return comprises a risk free rate and a risk premium (Sharpe, 1964; Lintner, 1965), an increase in the Treasury Bills rate should translate into a corresponding 
increase in the required rate of return and, by extension, to a rise in stock market returns. However, since the Treasury Bills commonly compete with stocks as an investment vehicle, investors are likely to reallocate more of their funds to the Treasury Bills and less to stocks following a rise in the Treasury Bills rates. This is because the Treasury Bills are relatively safer since they have an assured payoff from the government.

Furthermore, firms listed at a stock market have an option of obtaining long term financing by issuing additional shares (equity financing) or taking loans from commercial banks (debt financing). However, firms often seek to minimize the cost of funds and maximize existing shareholders' wealth. Therefore, lower lending rates could induce firms to use more loans from banks and issue fewer additional shares with a view to reducing the cost of capital while minimizing the chances of diluting existing shares. Thus, lower lending rates are expected to translate into rising stock market returns (Kganyago \& Gumbo, 2015). On the other hand, high lending rates might force firms to issue more shares in order to raise investment finances. This could in turn drive down share prices and lead to a decline in stock market returns. Rising lending rates could also increase interest expenses and reduce cash flows and stock market returns.

The importance of a clear understanding of the stochastic properties of stock market returns, 3-month Treasury Bills rate, lending rate and the respective cointegrating residuals can therefore not be over-emphasized. However, literature on the stochastic properties of these individual variables remains mixed and inconclusive. For instance, most studies employ standard unit root tests and either conclude that stock market returns and the 3-month Treasury Bills rate are stationary in levels (Kganyago \& Gumbo, 2015; Ouma \& Muriu, 2014) or that the 3 -month Treasury Bills rate is nonstationary in level while stock market returns are stationary (Kirui, Wawire, \& Onono, 2014) in level form. Equally, other studies establish that the 3-month Treasury Bills rate and stock market returns are nostationary in level form (Pal \& Mittal, 2011). In contrast, Anoruo and Gil-Alana (2011) demonstrate that stock market returns possess long memory while Caparole and Gila-Alana (2010) reveal that the 3-month Treasury Bills rate and lending rate have non-integer orders of integration greater than 1.

Additionally, most studies presume that interest rate and stock market returns are cointegrated in the conventional form such that deviations from long run equilibrium are eroded rapidly. This does not need to be the case since cointegrating residuals themselves might be long memory processes (Cheung, 2007; Caporin, Ronaldo, \& Santucci de Magistris, 2011). Furthermore, despite the evidence that stock market returns, the 3 -month Treasury Bills rate and lending rate in Kenya have non-integer orders of integration (Anoruo \& Gil-Alana, 2011; Caparole \& Gil-Alana, 2010), no study has examined the possibility of fractional cointegration between the variables. The main objective of this study was to examine the relationship between interest rate and stock market returns within the context of an Auto-Regressive Fractionally Integrated Moving Average (ARFIMA) framework.

Consistent with the research problem, this study sought to address the following research questions: First, to what extent do stock market returns evolve over time through non-integer orders of integration in Kenya? Second, to what extent do interest rates evolve over time through non-integer orders of integration in Kenya? Finally, to what degree do the cointegrating residuals between interest rate and stock market returns evolve over time through non-integer orders of integration in Kenya?

The rest of the paper is organized as follows. Section 2 provides a brief literature review while section 3 outlines the adopted research methodology. Section 4 discusses the data and sources. The empirical results and their discussion are presented in section 5 while section 6 concludes.

\section{Literature Review}

Several theories have been used to explain the relationship between interest rate and stock market returns. For instance, Modern Portfolio Theory (MPT) by Markowitz (1959) states that the returns of a financial asset are only influenced by systematic or market risk. The theory asserts that the market risk is highly correlated across securities and includes macroeconomic variables such as interest rate, inflation rate and exchange rate. However, the MPT does not indicate how to measure risk as well as how risk is related to expected or required returns. Sharpe (1964) and Lintner (1965) addressed this limitation of the MPT by introducing the Capital Asset Pricing Model (CAPM). This model asserts that risk is positively related to required returns of an asset through a model represented as:

$$
\mathrm{E}\left[\mathrm{R}_{\mathrm{i}}\right]=\mathrm{R}_{\mathrm{f}}+\beta_{\mathrm{i}}\left(\mathrm{E}\left[\mathrm{R}_{\mathrm{m}}\right]-\mathrm{R}_{\mathrm{f}}\right) .
$$

Where $E\left[R_{i}\right]$ is the return required by investors to induce them into putting their money in stock given the stock's riskiness, $E\left[R_{m}\right]$ is the expected return on the market portfolio, $\beta_{i}$ measures the sensitivity of security $\mathrm{i}$ to the returns of the market portfolio and $R_{f}$ is the risk free rate. Usually, investors use yields in government 
debt instruments such as the Treasury Bills rates to represent the risk free rate. $\left[E\left(R_{m}\right)-R_{f}\right]$ is the market risk premium which like the required return, depends strictly on the stock's future cash flows.

Nevertheless, the CAPM does not clearly demonstrate how the risk free rate directly relates to stock market returns. This however becomes clearer in the Free Cash Flow to Equity (FCFE) model developed by Copeland, Koller and Murrin (1994) and Damadoran (1998). Therefore assuming that stocks are efficiently priced, the value of a stock should equal its price such that:

$$
N R_{t}=\sum_{t=1}^{\infty} \frac{F C F E_{t}}{\left\{1+R_{f}+\beta_{i}\left[\mathrm{E}\left(\mathrm{R}_{\mathrm{m}}\right)-\mathrm{R}_{\mathrm{f}}\right]^{t}\right\}}
$$

where $N R_{t}$ is the stock market return today, $F C F E_{t}$ is the free-cash-flow-to- equity at time $t$ and measures the amount of cash flows generated in period $\mathrm{t}$ which is available for distribution to common shareholders.

Clearly, the FCFE model demonstrates that a rise in the risk free rate increases the denominator and results into declining stock market returns. Hence, using the Treasury Bills rate as a proxy for risk free rate, an increase in the Treasury Bills rate should translate into declining stock market returns. Additionally, assuming that firms listed at a stock market can finance their investments through commercial bank loans (debt financing), rising lending rates are expected to increase interest expenses on loans and reduce investments, including future cash flows.

Thus while CAPM suggests that stock market returns are positively related to interest rate risk (captured by beta) such that assets with high risks are associated with high returns, the FCFE demonstrates that interest rate is negatively related to stock market returns.

Equally, empirical literature on the stationarity of interest rate and stock market returns remains controversial. This is because while some authors concluded that the two variables were nonstationary in their level form (Erita, 2014; Gohar, Zaman, \& Baloch, 2014; Pal \& Mittal, 2011), others asserted that stock market returns were stationary in level form (Amarasinghe, 2015; Kirui et al., 2014) whereas interest rates were nonstationary in levels (Amarasinghe, 2015; Gohar et al., 2014). Some authors also concluded that stock market returns and interest rate were both stationary in level form (Ouma \& Muriu, 2014).

These studies however appear to have assumed that stock market returns and interest rates individually evolve over time only through integer orders of integration. This has however been challenged by studies which established that stock market returns, 3-month Treasury Bills rate and lending rate had non-integer orders of integration (Anoruo \& Gila-Alana, 2011; Caparole \& Gila-Alana, 2010). In particular, using Whittle estimator, Robinson (1995) and data from Kenya over the period 1991:07-2009:03, Caparole and Gil-Alana (2010) established that lending rate, 3-month Treasury Bills rate and deposit rate had orders of integration greater than 1 , suggesting long memory with no mean reversion. Likewise, using Robinson (1994) and monthly data from Kenya over the period 1993-2006, Anoruo and Gila-Alana (2011) found that the NSE 20 Share Index returns had a non-integer order of integration greater than 1 .

Similarly, previous results based on long run relationship as well as on the direction of causality assumed that the cointegrating residual needed to be stationary in the strictest sense. Such studies therefore adopted only standard cointegration and Granger causality frameworks. This however is not a necessary condition (Cheung, 2007; Caporin et al., 2011) since the cointegrating residuals themselves could be long memory processes. For instance, Jawaid and Anwar (2012) employed the error correction model (ECM) on monthly short term interest rate and banking sector stock returns from Pakistan over the period 2004:01-2010:12. The authors concluded that a significant negative short-run relationship existed between the short term interest rates and stock market returns. This provided support for the predictions of the Free Cash Flow to Equity model (Copeland et al., 1994; Damadoran, 1998). It also implied that rising interest rate could depress the performance of the stock market either by reducing the uptake of credit and constraining investments or by shifting investments from stocks to more profitable bank deposits or fixed income securities. On the other hand, Gohar et al. (2014) established, through ECM, that a significant short run and long run relationship existed between interest rate and stock market returns in Pakistan but failed to establish any form of causality between the two variables. This suggested that though the variables moved together in the long run, fundamentals that drove them were different such that past values of one variable did not contain predictive information for the future values of the other.

However, interestingly, using VECM, Kganyago and Gumbo (2015) found a short run causality from stock market returns to interest rates, but a long run causality from interest rate to stock returns in Zimbabwe. This suggested that whereas developments in the stock market had implications for the money market in the short run, the events in the money market significantly influenced the developments in the country's stock market in the 
long run. Similarly, Akbar, Ali, and Khan (2012) applied VECM to examine the relationship between the Treasury Bills rate, CPI and stock market returns over the period 1994 to 2011 in Pakistan. They established that the Treasury Bills rate had a positive relationship with stock returns in the short run. This suggested that investments in the Pakistan stock market continued in the short run even when the Treasury Bills rate was on the upward trend. A possible explanation for this trend may be that investors in Pakistan viewed the Treasury Bills rate as a risk free rate and demanded for higher required rate of return. This could also mean that most investors in Pakistan had long investment horizons and were thus not concerned with fluctuations in short term interest rate measures such as the variations in the Treasury Bills rate.

In summary therefore, there is no unanimity within the theoretical as well as empirical literature on the relationship between interest rate and stock market returns. Furthermore, despite the evidence that stock market returns, 3-month Treasury Bills rate and lending rate in Kenya possess long memory (Anoruo \& Gil-Alana, 2011; Caparole \& Gil-Alana, 2010), no study has examined the possible existence of a fractional cointegration between stock market returns and each of the measures of interest rate in Kenya.

\section{Empirical Models}

\subsection{Univariate ARFIMA Models: Fractional Integration}

This study followed Anoruo and Gila-Alana (2011) and adopted an ARFIMA model to determine the integration orders of stock market returns and each of the measures of interest rate namely; the 3-month Treasury Bills rate and the commercial banks' weighted average lending rate. However, while Anoruo and Gila-Alana (2011) used Robinson's (1994) parametric approach, this study employed the EML (Sowell, 1992) based on the following models:

$$
\begin{gathered}
(1-L)^{d 1} N R_{t} . \\
(1-L)^{d 2} T B 3_{t .} \\
(1-L)^{d 3} L r_{t} .
\end{gathered}
$$

where $(1-L)^{d 1} N R_{t}$ denotes the fractionally differenced stock market returns, $(1-L)^{d 2} T B 3_{t}$ represents the fractionally differenced 3-month Treasury Bills rate, and $(1-L)^{d 3} L r_{t}$ is the fractionally differenced commercial banks' weighted average lending rate.

\subsection{Bivariate ARFIMA Models: Fractional Cointegration}

The study hypothesized that the 3-month Treasury Bills rate, lending rate and stock market returns might be fractionally integrated variables. Therefore, following Cheung (2007), it fitted the following univariate ARFIMA models on the respective cointegrating residuals to investigate presence of a bivariate fractional cointegration between each measure of interest rate and stock market returns:

$$
\begin{gathered}
(1-L)^{4} \text { Rnrtb3t. } \\
(1-L)^{d 5} \text { Rnrlrt. }
\end{gathered}
$$

Where Rnrtb3 ${ }_{t}$ and Rnrlrt are the respective cointegrating residuals.

Presence of cointegration suggests that there must be causality at least in one direction (Engle \& Granger, 1987). This study therefore examined existence of causality between the variables using both first and fractionally differenced data.

\subsection{Granger Causality Using First Differenced Data}

To investigate presence of short run as well as the long run causal effects between the two measures of interest rate and stock market returns, this study estimated the following standard Granger causality models (Engle \& Granger, 1987):

$$
\left.\begin{array}{l}
\left.\begin{array}{l}
\Delta N R_{t}=\gamma_{0}+\sum_{j=1}^{m} \Phi_{11}^{j} \Delta N R_{t-j}+\sum_{j=1}^{n} \Phi_{12}^{j} \Delta T B 3_{t-j}+\psi_{o} R n r t b 3_{t-1}+G_{1 t} \\
\Delta T B 3_{t}=\gamma_{1}+\sum_{j=1}^{m} \Phi_{21}^{j} \Delta N R_{t-j}+\sum_{j=1}^{n} \Phi_{22}^{j} \Delta T B 3_{t-j}+\psi_{0} R n r t b 3_{t-1}+G_{2 t}
\end{array}\right\} . \\
\Delta N R_{t}=\gamma_{2}+\sum_{k=1}^{m} \theta_{11}^{k} \Delta N R_{t-k}+\sum_{k=1}^{n} \theta_{12}^{k} L r_{t-k}+\psi_{1} \text { Rnrl }_{t-1}+G_{3 t} \\
\Delta L r_{t}=\gamma_{3}+\sum_{k=1}^{m} \theta_{21}^{k} \Delta N R_{t-k}+\sum_{k=1}^{n} \theta_{22}^{k} \Delta L r_{t-k}+\psi_{1} \text { Rnrl }_{t-1}+G_{4 t}
\end{array}\right\} .
$$


Where $\psi_{1}$ is the adjustment coefficient which shows how fast deviations from the long run equilibrium get eroded. The short run causality was examined by testing: $H_{o}: \theta_{12}=0$ and Ho: $\theta_{21}=0$ for all $\mathrm{k}$ while the long-run causality was investigated, for instance, by testing: $H o: \psi_{1}=0$. The optimal lag lengths were determined from the models with lowest AIC.

\subsection{Granger Causality Using Fractionally Differenced Data}

Majority of the economic and financial time series such as stock market returns and interest rate are neither nonstationary in levels nor stationary in first difference (Teyssiere \& Kirman, 2007). This study therefore extended the concept of Granger causality to the more general and flexible fractionally integrated error correction model (FIECM). This is because the cointegrating residuals themselves might have non-integer orders of integration (Cheung, 2007; Caporin et al., 2011). It employed the following Granger causality models:

$$
\left.\begin{array}{c}
(1-L)^{d 1} N R_{t}=\gamma_{4}+\sum_{i=1}^{m} \Upsilon_{11}^{i}(1-L)^{d 1} N R_{t-i}+\sum_{i=1}^{n} \Upsilon_{12}^{i}(1-L)^{d 2} T B 3_{t-i}+\psi_{3} f d R n r t b 3_{t-1}+G_{5 t} \\
(1-L)^{d 2} T B 3_{t}=\gamma_{5}+\sum_{i=1}^{m} \Upsilon_{21}^{i}(1-L)^{d 1} N R_{t-i}+\sum_{i=1}^{n} \Upsilon_{22}^{i}(1-L)^{d 2} T B 3_{t-i}+\psi_{3} f d R n r t b 3_{t-1}+G_{6 t}
\end{array}\right\} .
$$

where $f d R n r t b 3_{t-1}$ and $f d R n r l r_{t-1}$ are fractionally integrated error correction terms (FIECTs) lagged one period, $\psi_{3}$ and $\psi_{4}$ are the long run adjustment parameters, $(1-\mathrm{L})^{d 1} \mathrm{NR}_{\mathrm{t}},(1-\mathrm{L})^{d 2} \mathrm{~TB} 3_{\mathrm{t}}$, and $(1-\mathrm{L})^{d 3} \mathrm{Lr}_{\mathrm{t}}$ are fractionally differenced stock market returns, 3-month Treasury Bills rate, and lending rate, respectively. The study examined the short run causality by testing: $H o: \Upsilon_{12}=0$ and $H_{0}: \Upsilon_{21}=0$ for all $\mathrm{i}$ in equation 10 as well as $H o: \Theta_{12}=0$ and $H o: \Theta_{21}=0$ for all $\mathrm{i}$ in equation 11. The long-run causality was investigated by testing: $H o: \psi_{3}=0$ and $H_{o}: \psi_{4}=0$ in equations 10 and 11 respectively. The optimal lag lengths were chosen from models with the lowest AIC.

\section{Data and Sources}

This study used monthly published time series data with the full sample period from $1^{\text {st }}$ January 1993 to $31^{\text {st }}$ December 2015 which yielded a total of 276 observations. The variables comprised monthly NSE 20 Share index drawn from Nairobi Securities Exchange (NSE) as well as the 3-month Treasury Bills rate and lending rate obtained from the Central Bank of Kenya (CBK). Table 1 provides the description and measurement of the variables.

Table 1. Description and measurement of stock returns and interest rate

\begin{tabular}{llll}
\hline Variable name & Notation & \multicolumn{1}{c}{ Measurement } \\
\hline $\begin{array}{l}\text { Monthly NSE } 20 \text { Share } \\
\text { Index nominal returns }\end{array}$ & $N R_{t}$ & $\begin{array}{l}\text { Proxy for the Security Exchange's performance. Computed as percentage change in } \\
\text { closing NSE 20 Share Index between successive months as: } N R_{t}=\ln \left(\frac{N S E_{t}}{N S E_{t-1}}\right) x 100, \\
\text { where NSE is the closing NSE 20 Share index at time t. } \\
\text { 3-month Treasury Bill rate }\end{array} \quad T B 3_{t} \quad \begin{array}{l}\text { The short term central bank rate taken as a risk free rate. Interest rate that the government } \\
\text { pays for borrowing in the short term. } \\
\text { The commercial banks' monthly weighted average lending rate. The amount that a lender } \\
\text { charges a borrower in order to make a loan. }\end{array}$ \\
Monthly lending rate & $L r_{t}$ &
\end{tabular}

\section{Empirical Results and Discussion}

\subsection{Descriptive Statistics}

Table 2 presents the summary statistics of stock market returns, 3-month Treasury Bills rate and lending rate. 
Table 2. Summary descriptive statistics

\begin{tabular}{cccc}
\hline & $N R_{t}$ & $T B 3_{t}$ & $L r_{t}$ \\
\hline Mean & 0.449 & 13.627 & 19.393 \\
Median & 0.185 & 9.255 & 18.12 \\
Maximum & 41.815 & 84.67 & 32.28 \\
Minimum & -25.667 & 0.83 & 11.9700 \\
Std. Dev. & 6.828 & 12.491 & 5.899 \\
Skewness & 0.96 & 3.228 & 0.684 \\
Kurtosis & 9.654 & 16.529 & 2.170 \\
Jarque-Bera & 551.511 & 2584.035 & 29.462 \\
Probability & 0.00000 & 0.00000 & 0.00000 \\
Sum & 124.175 & 3761.01 & 5352.49 \\
Sum Sq. Dev. & 12819.48 & 42908.16 & 9569.753 \\
Observations & 276 & 276 & 276 \\
\hline
\end{tabular}

Note. $N R_{t}$ is $\log$ difference of the NSE 20 Share Index, TB3t is the 3-month Treasury Bills rate, and $L r_{t}$ is the commercial banks' weighted average lending rate.

Table 2 reveals that the mean values of all the variables are positive with the mean of lending rate being much higher than that of the 3-month Treasury Bills rate while that of stock market returns is the lowest. This suggests that higher values of both measures of interest rate could have depressed the performance of the stock market. Furthermore, the 3-month Treasury Bills rate and stock market returns recorded excess positive kurtosis (since the kurtosis of the variables exceed the normal value of 3), suggesting that they individually posed lesser risk of extreme outcomes. Additionally, all the variables had positive skewness which implies that their actual values were likely to deviate further upwards from their mean values.

Furthermore, the wide range in the 3-month Treasury Bills rate (see maximum of 84.67 versus minimum of 0.83 ) suggests that demand for the government short term debt instrument might have increased significantly over the period. However, the low mean coupled with the large negative minimum (see minimum of -25.67) suggests that demand for the stock market returns might have significantly decreased over the period. The two developments suggest that most investors might have shifted from the stock market to the 3-month Treasury Bills over the period.

\subsection{Univariate ARFIMA Analyses: Fractional Integration}

This study empirically estimated the integration orders of stock market returns, the 3-month Treasury Bills rate, and lending rate. It fitted ARFIMA (p, d, q) model, ranging from ARFIMA $(0, d, 0)$ to $\operatorname{ARFIMA}(3, \mathrm{~d}, 3)$ to each of the variables and obtained sixteen competing models. It then chose the models with both significant AR and MA components, no autocorrelation in residuals and lowest AIC out of the sixteen competing models to represent each of the time series. Table 3 presents results of the chosen models for stock market returns, 3-month Treasury Bills rate and lending rate which are described by equations 3, 4 and 5.

Table 3. Results of long memory estimates for the individual variables using EML

\begin{tabular}{cccccc}
\hline Variable notations & ARMA(p,q) & $\hat{d}$ & $S . E(\hat{d})$ & $t_{H 0: d=0}=\frac{\hat{d}-d}{S . E(\hat{d})}$ & $t_{H 0: d=1}=\frac{\hat{d}-d}{S . E(\hat{d})}$ \\
\hline$N R_{t}$ & $(2,2)$ & 0.231 & 0.05 & 4.37 & -14.61 \\
$T B 3_{t}$ & $(1,3)$ & 0.314 & 0.14 & 2.29 & -5.01 \\
$L r_{t}$ & $(3,2)$ & 0.404 & 0.07 & 5.74 & -8.47 \\
\hline
\end{tabular}

Note. The long memory estimates were analysed at the 5\% significance level (Gil-Alana, 2001). NRt is the log difference of the NSE 20 Share Index, $T B 3_{t}$ is the 3-month Treasury Bills rate and $L r_{t}$ is the commercial banks' weighted average lending rate. S.E( $(\hat{d})$ is standard error of the differencing parameter.

Table 3 reveals that the appropriate models for the individual variables include the AR and MA components. On average, higher order models or models with AR and MA parts of order 2 and above seem to be more suitable for modelling the variables except the model for lending rate which has a lower order for the AR part. Moreover, there is no model where the white noise specification of the short memory components or ARMA $(0,0)$ is preferred. 
The results also reveal that the estimated values of $d$ parameter range from 0.231 to 0.404 (implying stationary long memory) and that none of the variables had short memory (i.e., $d=0)$. This suggests that all the variables, though exhibiting different levels of persistence, returned to their equilibrium values after experiencing a shock. It further demonstrates that expected future increments or declines in the individual variables were predictable, giving speculators an opportunity to consistently make profits with no input of funds.

Furthermore, the results indicate that lending rate was the most persistent but reverted back to its pre-shock level albeit at the lowest rate. On the other hand, the positive sign of the $d$ parameters for all the variables suggests that increases in each of them were followed by increases whereas decreases triggered further decreases. Moreover, all the d parameters were significantly different from 0 and 1 , based on the hypotheses tests. This confirms that the individual variables were indeed long memory processes. The results, however, contradict Anoruo and Gil-Alana (2011) who concluded that the NSE 20 Share index returns had an integer order of integration greater than 1, implying no mean reversion. This difference might be attributed to the fact that while Anoruo and Gil-Alana (2011) used Robinson (1994) test, this study employed the more superior EML procedure to estimate the integration orders (Dalhaus, 2006; Miller \& Miller, 2003).

\subsection{Bivariate ARFIMA Analysis: Fractional Cointegration}

This study also investigated whether the cointegrating residuals between each of the measures of interest rate and stock returns were long memory processes. To do this, it fitted ARFIMA models to the respective cointegrating residuals (see equations 6 and 7) to determine whether each of them had an integration order lower than the integration orders of the parent time series (Cheung, 2007).Table 4 presents the results, including the hypotheses tests.

Table 4. Hypotheses tests for d parameter for the cointegrating residuals using EML

\begin{tabular}{cccccc}
\hline Cointegrating residuals & ARMA(p,q) & $\hat{d}$ & $S . E(\hat{d})$ & $t_{H 0: d=0}=\frac{\hat{d}-d}{S . E(\hat{d})}$ & $t_{H 0: d=1}=\frac{\hat{d}-d}{S . E(\hat{d})}$ \\
\hline Rnrtb3t & $(2,2)$ & 0.213 & 0.05 & 3.98 & -14.72 \\
Rnrlr $r_{t}$ & $(2,2)$ & 0.228 & 0.05 & 4.36 & -14.7 \\
\hline
\end{tabular}

Note. The long memory estimates are usually analysed at the $5 \%$ significance level (Gil-Alana, 2001. Rnrtb3 $t$ is the cointegrating residual from regressing stock market returns on 3-month Treasury Bills rate and $R n r l r_{t}$ is the cointegrating residual from regressing stock market returns on lending rate. $S . E(\hat{d})$ is standard error of the differencing parameter.

Table 4 demonstrates that both cointegrating residuals are stationary long memory processes. Besides, the $d$ parameters of the cointegrating residuals are each less than the absolute values of the $\mathrm{d}$ parameters associated with the respective parent time series (refer to Table 3). This means that despite the different non-integer orders of integration of the individual variables, a stable linear combination with a lower order of non-integer integration does exist between the variables. Consequently, this study concluded that stock market returns are fractionally cointegrated with each of the measures of interest rate in Kenya (Caporin et al., 2011; Cheung, 2007).

These results suggest that active policy intervention is required to induce faster adjustment to long run equilibrium should external shocks drive stock market returns away from each of the measures of interest rate. Furthermore, existence of cointegration between variables implies that there should be a causal relationship in at least one direction (Engle \& Granger, 1987). To test this, the study employed the conventional ECM as well as a Fractionally Integrated Error Correction Model (FIECM).

\subsection{Results of Granger Causality Tests using First and Fractionally Differenced Variables}

The study estimated error correction models represented by equations 8 and 9 to determine presence of conventional causality between the two measures of interest rate and stock market returns. It also estimated the fractionally integrated error correction models (FIECM) given by equations 10 and 11 to test for existence of fractional Granger causality between each of the two measures of interest rate and stock market returns. Table 5 provides a summary of the results from the ECM and FIECM-based Granger causality tests. More detailed results are contained in Table 6 . 
Table 5. Estimates of Granger causality using first and fractionally differenced data

\begin{tabular}{lccc}
\hline Dependent variables & & Sources of Causation & \\
\hline \multirow{2}{*}{$N R_{t}$} & $N R_{t}$ & $T B 3_{t}$ & $L r_{t}$ \\
& - & {$[-\mathbf{0 . 8 5 4}]^{* * *}$} & $(-\mathbf{0 . 8 1 2}]^{* * *}$ \\
$T B 3_{t}$ & & $(-7.546)$ & $(13.026)^{* * *}$ \\
& {$[\mathbf{0 . 0 2 6}]$} & - & \\
$L r_{t}$ & $(8.896)^{* *}$ & & \\
& {$[-\mathbf{0 . 0 1 2}]$} & $(1.294)^{*}$ & \\
\hline
\end{tabular}

Note. The coefficients of the error correction terms lagged one period for the ECM-based Granger causality models are in bold within parenthesis while those based on FIECM are in brackets. *** $1 \%$ significance, $* * 5 \%$ significance, $* 10 \%$ significance. $N R_{t}$ is log difference of the NSE 20 Share Index, $T B 3_{t}$ is the 3-month Treasury Bills rate and $L r_{t}$ is the commercial banks' weighted average lending rate.

The results demonstrate that based on the ECM, a significant unidirectional long run Granger causality runs from the 3-month Treasury Bills rate as well as lending rate to stock market returns. The results specifically reveal that the 3-month Treasury Bills rate as well as lending rate negatively Granger caused stock market returns in the long run (see coefficient of lagged first difference of $T B 3_{t}$ and $L r_{t}$ in Table 6). This suggests that in the long run, investors in Kenya consider the short term government debt instrument as a competing investment vehicle such that when the rate rises, they reallocate more funds to the portfolio of the 3-month Treasury Bills and less to stocks. Likewise, the negative long run causal effect from lending rate to stock market returns suggests that when banks increase the cost of capital, individual investors and firms reduce the uptake of investment finances. This reduces expansion of existing investments as well as the initiation of new investments and leads to declining cash flows and stock market returns. These results are consistent with those established by Ado and Sunzuoye (2013) and Amarasinghe (2015). However, the results contradict those by Erita (2014) and Chirchir (2014) who found bidirectional long run Granger causality between the two variables in Namibia and Kenya respectively.

However, the ECM tests failed to establish any short run causality between either of the measures of interest rate and stock market returns (see Table 6). This suggests that the Kenyan government can implement interest rate management policies without adverse effects on the stock market in the short run. In direct contrast, the FIECM results reveal a negative unidirectional Granger causality from the stock market returns to the 3-month Treasury Bills rate and lending rate. This suggests that an increase in past values of stock market returns has predictive power on the future values of the 3-month Treasury Bills rate and lending rate. Therefore, the ECM and FIECM results indicate that the relationship between interest rate and stock market returns might be more complex than has been demonstrated by existing literature.

Table 6. Bivariate Granger causality for stock market returns and interest rate

\begin{tabular}{|c|c|c|c|c|c|c|}
\hline \multicolumn{7}{|c|}{ PANEL A: Results from Regressing Stock Market Returns $\left(N R_{t}\right)$ on Short Term Interest Rate $\left(T B 3_{t}\right)$} \\
\hline & \multicolumn{3}{|c|}{ First Differenced Model } & \multicolumn{3}{|c|}{ Fractionally Differenced Model } \\
\hline & Coefficient & Std. Error & t-ratio & Coefficient & Std. Error & t-ratio \\
\hline Intercept & -0.022 & 0.403 & -0.054 & 0.419 & 0.649 & 0.645 \\
\hline dTB3t-1 & -0.297 & 0.286 & -1.042 & -0.502 & 0.509 & -0.985 \\
\hline Rnrtb3t-1 & -0.854 & 0.141 & $-6.054 * * *$ & -7.546 & 6.554 & -1.151 \\
\hline dNRt-1 & 0.079 & 0.14 & 0.566 & 7.552 & 6.598 & 1.145 \\
\hline dNRt-2 & 0.023 & 0.071 & 0.323 & -0.011 & 0.127 & -0.085 \\
\hline \multicolumn{7}{|c|}{ PANEL B: Results from Regressing Short Term Interest $\left(T B 3_{t}\right)$ on Stock Market Returns $\left(N R_{t}\right)$} \\
\hline & \multicolumn{3}{|c|}{ First Differenced Model } & \multicolumn{3}{|c|}{ Fractionally Differenced Model } \\
\hline & Coefficient & Std. Error & t-ratio & Coefficient & Std. Error & t-ratio \\
\hline Intercept & -0.043 & 0.132 & -0.328 & -0.529 & 0.310 & $-1.706^{*}$ \\
\hline dNRt-1 & -0.029 & 0.029 & -0.996 & -8.898 & 4.055 & $-2.195 * *$ \\
\hline dNRt-2 & -0.022 & 0.013 & -1.624 & -0.153 & 0.064 & $-2.393 * *$ \\
\hline Rnrtb3t-1 & 0.026 & 0.039 & 0.649 & 8.896 & 4.068 & $2.187 * *$ \\
\hline dTB3t-1 & 0.652 & 0.119 & $5.461 * * *$ & 1.633 & 0.353 & $4.621^{* * * *}$ \\
\hline
\end{tabular}




\begin{tabular}{|c|c|c|c|c|c|c|}
\hline & \multicolumn{3}{|c|}{ First Differenced Model } & \multicolumn{3}{|c|}{ Fractionally Differenced Model } \\
\hline & Coefficient & Std. Error & t-ratio & Coefficient & Std. Error & t-ratio \\
\hline Intercept & -0.021 & 0.408 & -0.051 & -0.806 & 0.526 & -1.532 \\
\hline dLrt-1 & -0.065 & 0.908 & -0.072 & 0.523 & 0.902 & 0.579 \\
\hline dLrt-2 & 0.809 & 0.621 & 1.305 & 0.892 & 0.873 & 1.023 \\
\hline dLrt-3 & 1.015 & 0.926 & 1.097 & -0.199 & 0.404 & -0.495 \\
\hline Rnrlrt-1 & -0.812 & 0.139 & $-5.847 * * *$ & 13.026 & 4.457 & $2.923 * * *$ \\
\hline dNRt-1 & 0.052 & 0.137 & 0.382 & -13.012 & 4.449 & $-2.924 * * *$ \\
\hline dNRt-2 & 0.007 & 0.072 & 0.103 & -0.175 & 0.096 & $-1.819 * *$ \\
\hline \multicolumn{7}{|c|}{ PANEL D: Results from Regressing Long Term Interest $\left(L r_{t}\right)$ on Stock Market Returns $\left(N R_{t}\right)$} \\
\hline & \multicolumn{3}{|c|}{ First Differenced Model } & \multicolumn{3}{|c|}{ Fractionally Differenced Model } \\
\hline & Coefficient & Std. Error & t-ratio & Coefficient & Std. Error & t-ratio \\
\hline Intercept & -0.003 & 0.038 & -0.0894 & 0.048 & 0.045 & 1.078 \\
\hline Rnrlrt-1 & -0.012 & 0.009 & -1.4417 & 1.294 & 0.704 & $1.839^{*}$ \\
\hline dNRt-1 & 0.009 & 0.008 & 1.0883 & -1.298 & 0.704 & $-1.843^{*}$ \\
\hline dNRt-2 & 0.005 & 0.006 & 0.8383 & -0.009 & 0.006 & -1.529 \\
\hline dLrt-1 & 0.264 & 0.089 & $2.967 * *$ & 0.909 & 0.098 & $9.274 * * *$ \\
\hline dLrt-2 & 0.128 & 0.066 & $1.948^{*}$ & 0.118 & 0.102 & 1.1583 \\
\hline dLrt-3 & 0.164 & 0.051 & $3.234 * *$ & 0.012 & 0.041 & 0.302 \\
\hline
\end{tabular}

Note. Heteroscedasticity and autocorrelation consistent (HAC) standard errors were used to obtain more efficient parameter estimates. $* * * 1 \%$ significance, $* * 5 \%$ significance $* 10 \%$ significance. $N R_{t}$ is log difference of the NSE 20 Share Index, TB3 ${ }_{t}$ is the 3-month Treasury Bills rate and $L r_{t}$ is the commercial banks' weighted average lending rate.

\section{Conclusion}

The purpose of this study was to establish the relationship between interest rate and stock market returns in Kenya, and to examine the long memory properties of the individual time series and their cointegrating residuals. The ARFIMA-based exact maximum likelihood (EML) approach was used to empirically determine the integration orders of the individual variables and that of the cointegrating residuals. The study also conducted conventional Granger causality as well as ARFIMA-based Granger causality tests to examine causal relationships between the measures of interest rate and stock market returns in a bivariate framework.

The ARFIMA-based EML test results provide support for long memory in all the individual variables and the cointegrating residuals. This suggests that arbitrageurs can consistently earn higher-than- average returns from the Kenyan stock market. This is because the future trends of stock market returns are highly predictable. On the other hand, the presence of long memory in the cointegrating residuals suggests that whenever each of the measures of interest rate is driven away from stock market returns, it takes longer for the pre-shock long run equilibrium to be restored. This might lead to the establishment of a new and harmful equilibrium level in the absence of active policy intervention.

The presence of long memory property in the individual variables as well as in the cointegrating residuals also indicates that investors, policymakers and financial practitioners need to be extra cautious while applying the standard statistical inferences and asset pricing models such as Capital Asset Pricing Model (CAPM). This is because these analytical procedures are based on the assumptions that the variables have normal distributions and short memory.

The results of this study also suggest that the Kenyan government needs to work closely with the Capital Markets Authority (CMA) and other regulators to improve the performance of the stock market. This is because this study established that a thriving stock market plays a significant role in enhancing macroeconomic stability.

The results of this study have provided the first evidence of fractional cointegration between interest rates and stock market returns in Kenya. The results have also extended the understanding of Granger causality from the conventional and restrictive approach to the more flexible ARFIMA-based Granger causality framework.

\section{References}

Addo, A., \& Sunzuoye, F. (2013). The Impact of Treasury Bills Rate and Interest Rate on Stock Market Returns: A Case of Ghana Stock Exchange. European Journal of Business and Economics, 8(2), 15-24. http://dx.doi.org/10.12955/ejbe.v8i2.378 
Akbar, M., Ali, S., \& Khan, M. F. (2012). The Relationship of Stock Prices and Macroeconomic Variables revisited: Evidence from Karachi Stock Exchange. African Journal of Business Management, 6(4), 1315-1322.

Amarasinghe, A. (2015). Dynamic Relationship between Interest Rate and Stock Price: Empirical Evidence from Colombo Stock Exchange. International Journal of Business and Social Science, 6(4), 92-97.

Anoruo, E., \& Gil-Alana, L. (2011). Mean Reversion and Long Memory in African Stock Market Prices. Journal of Economics and Finance, 35(3), 296-308. http://dx.doi.org/10.1007/s12197-010-9124-0

Caporale, G. M., \& Gil-Alana, L. A. (2010). Interest Rate Dynamics in Kenya: Commercial Banks' Rates and the 91-Day Treasury Bill Rate. Economics and Finance Working Paper Series, No. 10-27.

Caporin, M., Ranaldo, A., \& Santucci de Magistris, P. (2011): On the Predictability of stock prices: A Case for High and Low Prices. Journal of Banking \& Finance, 37(12), 5132-5146. http://dx.doi.org/10.1016/j.jbankfin.2013.05.024

Chen, N. F., Roll, R., \& Ross, S. (1986). Economic Forces and the Stock Market. Journal of Business, 59(3), 383-403. http://dx.doi.org/10.1086/296344

Cheung, Y. (2007). An Empirical Model of Daily Highs and Lows. International Journal of Finance and Economics, 12(1), 1-20. http://dx.doi.org/10.1002/ijfe.303

Chirchir, D. (2014). The Relationship Between Share Prices and Interest Rates: Evidence From Kenya. Journal of Finance and Investment Analysis, 3(2), 91-98.

Copeland, T., Koller, T., \& Murrin, J. (1994). Valuation: Measuring and Managing the Value of Companies (2nd ed.). New York: Willey \& Sons, Inc.

Dalhaus, R. (2006). Correction Efficient Parameter Estimation for Self-Similar Processes. The Annals of Statistics, 34(2), 1045-1047. https://doi.org/10.1214/009053606000000182

Damodaran, A. (1998). Applied Corporate Finance: A User's Manual. New York: John Willey \& Sons.

Engle, R., \& Granger, C. (1987). Cointegration and Error Correction: Representation Estimation, and Testing. Econometrica, 55(2), 251-276. http://dx.doi.org/10.2307/1913236

Erita, J, H. (2014). Interest Rate and Stock Market Returns in Namibia. International Business and Economics Research Journal, 13(4), 689-696.

Gohar, A., H., Zaman, G., \& Baloch, O, B. (2014). The Causal Relationship of Interest Rate and Stock Prices: Empirical Evidence from Pakistani Markets. City University Research Journal, 4(2), 147-155.

Gupta, R. D., \& Modise, M. P. (2013). Macroeconomic Variables and South African Stock Return Predictability. Economic Modelling, 30, 612-622. http://dx.doi.org/10.1016/j.econmod.2012.10.015

Hamrita, M. E., \& Trifi, A. (2011). The Relationship between Interest Rate, Exchange Rate and Stock Price: A Wavelet Analysis. International Journal of Economics and Financial Issues, 4, 220-228.

Hautcoeur, P. C. (2011). Why and How to Measure Stock Market Fluctuations? The Early History of Stock Market Indices, with Special Reference to the French Case. Working Paper No. 2006 - 10

Jawaid, S. T., \& Anwar, U. H. (2012). Effects of Interest Rate, Exchange Rate and their Volatilities on Stock Prices: Evidence from Banking Industry of Pakistan. Theoretical and Applied Economics, 19(8), 153-166.

Kganyago, T., \& Gumbo, V. (2015). An Empirical Study of the Relationship between Money Market Interest Rates and Stock Market Performance: Evidence from Zimbabwe (2009-2013). International Journal of Economics and Financial Issues, 5(3), 638-646.

Kirui, E., Wawire, H. W. N., \& Onono, P. O. (2014). Macroeconomic Variables, Volatility and Stock Market Returns: A Case Study of Nairobi Securities Exchange, Kenya. International Journal of Economics and Finance, 6(8), 214-228. http://dx.doi.org/10.5539/ijef.v6n8p214

Lintner, J. (1965). The Valuation of Risk Assets and the Selection of Risky Investments in Stock Portfolios and Capital Budgets. Review of Economics and Statistics, 47(1) ,13-37. http://dx.doi.org/10.2307/1924119

Lo, A. W., Campbell, J. Y., \& Mackinlay, A. C. (1997). The Econometrics of Financial Markets. New Jersey: Princeton University.

Markowitz, H. (1952). Portfolio Selection. Journal of Finance, 7(1), 77-91. http://dx.doi.org/10.1111/j.1540-6261.1952.tb01525.x 
Miller, I., \& Miller, M. (2003). John E. Freund's Mathematical Statistics with Applications (7th ed.). New Jersey: Pearson Education, Prentice Hall.

Ouma, W. O., \& Muriu, P. W. (2014). The Impact of Macroeconomic Variables on Stock Market Returns in Kenya. International Journal of Business and Commerce, 3(11), 01-31.

Pal, K., \& Mittal, R. (2011). Impact of Macroeconomic Indicators on Indian Capital Markets. Journal of Risk Finance, 12, 84-97. http://dx.doi.org/10.1108/15265941111112811

Robinson, P. M. (1994). Semiparametric Analysis of Long Memory Time Series. Annals of Statistics, 22, 515-539. http://dx.doi.org/10.1080/01621459.1994.10476881

Sharpe, W. F. (1964). Capital Asset Prices: A Theory of Market Equilibrium Under Conditions of Risk. The Journal of Finance, 19(3), 425-442. http://dx.doi.org/10.2307/2977928

Sowel, F. (1992). Maximum Likelihood Estimation of Stationary Univariate Fractionally Integrated Time Series Models. Journal of Econometrics, 53(1), 165-188. https://doi.org/10.1016/0304-4076(92)90084-5

Teyssiere, G., \& Kirman, A. P. (2007). Long Memory in Economics. New York: Springer Berlin Heidelberg. https://doi.org/10.1007/978-3-540-34625-8

\section{Copyrights}

Copyright for this article is retained by the author(s), with first publication rights granted to the journal.

This is an open-access article distributed under the terms and conditions of the Creative Commons Attribution license (http://creativecommons.org/licenses/by/4.0/). 